\title{
Formation of the basic principles of ethics for specialists of accounting and analytical sciences in modern information economics
}

\begin{abstract}
The article considers the process of the formation of basic principles of the ethics for the specialists of the accounting and analytical sciences. The authors provide the insight into the little-known historical information about the appearance of the key principles and requirements to the training of specialists as exemplified by the Ukrainian cooperation, including the accountants, advisors and auditors. The paper determines the structure of specialists in the accounting and analytical sciences in modern information economics, which includes the professional accountants and auditors, officials of the state control authorities and court experts. The content of the principles is shown, with which they are governed in the context of the Ethics Standards, as well as the possible security measures for the elimination and reduction of the risk of their violation. The article proposes the ways of harmonization of the norms of regulating the relations existing in Ukraine in compliance with the Accountant and Auditor Ethics Standards by all specialists, including the officials of the state control authorities and court experts.
\end{abstract}

Keywords: auditors; accountant; expert; ethics; accounting and analytical sciences; principles; forensic audit; specialist.

Actuality of the research and settlement of the problem. The accuracy of the economic indexes under the conditions of modern information technologies mostly depends upon the information of the official reports of business entities. The topicality of this statement is confirmed by the key reasons of the global financial crisis occurrence in 2008 when the administrative personnel of the large banks and companies falsified the report indices in their favor, which created the «financial bubbles» that led to passing the erroneous decisions based on this information. At the same time, it is widely known that the information should comply with the requirements of acting law and should be confirmed (for the publically important business entities) by the auditors, who are the specialists in the accounting and analytical sciences. If the form and content of the financial reporting legally specify the requirements to the information about the business entities' activity, the liability of the specialists as to the accuracy of the performance of professional functions mostly depends upon their compliance with the basic principles of ethics of the accountant and auditor formed in the Standards of professional accountants developed by the International Ethics Standards Board for Accountants. The Professional Accountants Ethics Standard was introduced in Ukraine by the Decision of Ukraine Chamber of Auditors dated 18.04.2003.

Analysis of the latest researches and publications. On a regular basis Ukrainian scholars pay attention to the issues of ethics and correct interpretation of its provisions, these, in particular, are the works by V.P. Bondar, S.F. Holova, O.Yu. Redko, O.B. Ryzhakova, etc. [1, 5, 9]. However, the wide spectrum of financial report users does not always clearly understand the importance and role of sticking to the basic principles of ethics of the professional auditors and accountants. The difficulty of the situation is aggravated by the existing stereotypes with regard to the attitude towards the officials of the supervisory authorities and court experts who also occupy an essential place amongst the specialists of the accounting and analytical sciences. Therefore, the studying of problems of the ethics of accounting and analytical sciences is a topical issue for researching.

Purpose of article The main purpose of this article is to elucidate the essence of the basic principles of ethics of the specialists in the accounting and analytical sciences, their perception and understanding in modern information economics characterized by a wide access of users to the reports of the business entities based on which the administrative decisions are passed. The achievement of this goal provides for the solution of the following issues: first, covers the historical resources of the formation of ethic standards of the specialists in the accounting and analytical sciences in Ukraine; second, provides the insight into the essence of the ethic standards of the specialists in the accounting and analytical sciences; third, clarifies the regulatory and legal grounds of the principles of activity of the specialists in the accounting and analytical sciences of the private and state sectors of the Ukrainian economy and possibilities of its harmonization in accordance with the international standards.

Statement of the research.

1. Historical origins of the formation of ethic standards of the specialists in accounting and analytical sciences. The historical origins of the formation of ethic standards of the specialists in the accounting and analytical sciences and their principles in Ukraine are connected with the activity of the Revision Union of Ukrainian Cooperative and one of its directors, namely Yulian Pavlykovsky. Paying attention to the training of the organizers of Ukrainian Cooperative movement, Yu.Pavlykovsky determined their object and objective [10]. 
In particular, the essence of the professional training contained three key elements, mainly: general education; the education of the individual and citizen; special training. Training of then specialists of cooperative movement was conducted within five specialties: a cooperator-economist, a cooperator-propagandist, a cooperatorcontroller, an inspector, an organizer and instructor-advisor. A special role was given by Yu.Pavlykovsky to the advisor-lustrator, who acted as a mediator between the cooperative hierarchy authorities in the union, on the one hand, and professional and ideological buildups, on the other hand, and his work was to comply with the grounds of ideology of cooperation and cooperative ethics. Pavlykovsky Yu. determined six basic standards, which the inspector-lustrator should have followed, mainly: the knowledge of the cooperation ideas and work methods; specificity and reliability; professionalism; the consistency based on the expertise; personal distinctness (charismaticity), which was a characteristic of each respected personality; belief in the cooperation. Intrinsically these parameters may be considered as the principles to be followed by the inspector-lustrator, and his specified tasks testify to the necessity of possessing the knowledge in accounting, analysis, control and taxation [10]. Apart from the requirements above, the advisors-lustrators have to comply with the special requirements depending upon the type of cooperation in which they work. These are the principles, which governed the Ukrainian cooperators in the Western Ukraine before joining the USSR. The Command and Administration System of economy management had a negative impact on the development of cooperation in Ukraine, and, basically, only after the regain of independence the attention returned to the principles of ethic standards for the specialists in accounting, analysis and control in practical activity and in educational process.

From our point of view, the process of formation of the professional ethics for the specialists in the accounting and analytical sciences in Ukraine under modern conditions should be considered in two directions, mainly: reorganization of the relations of specialists in the sphere of public sector, and formation of the selfregulating system of relations among the specialists of the private economy sector. At the same time, the reforming in the public sector due to the impossibility to eliminate immediately the traditions of the Command and Administration System led to the acceleration of the process of introducing the basic ethic standards in the private sector with the participation of international organizations. Therefore, the experience of the private sector has all the grounds to serve as the raw model of the relations with regard to the introduction of basic principles in the sphere of public sector.

2. Object and objective of the Ethics Standards of professional accountants as a benchmark of training specialists in accounting and analytical sciences.

It is widely known that the key objective of the Ethics Standards is the establishment of the ethical requirements for the practising auditors and professional accountants for the purpose of insuring the guarantee of their work quality and serving the interests of the society and state [4]. The standards are composed of three parts, the first one provides the insight into the general grounds of its application, the second one covers the ethical issues for the professional practising accountants, and the third one covers the ethical issue for the professional accountants in business. It is necessary to mention that the key factor of the Standards is represented by the fundamental principles of the professional ethics of accountants and auditors, who constitute the conceptual grounds of their behavior and relations in the sphere of business. The idea of formation and acceptance of the Accountants' Ethic Standards allows for analyzing the following key objectives: first of all, the identification of risks as to the following the fundamentals principles; secondly, the assessment of the identification risks; thirdly, the application of the corresponding preventive measures necessary for the elimination of the identified dangers or reduction of risks of their occurrence to the acceptable management level. In this case, it should be taken into account that the Ethic Standards single out the professional practising accountants (render the services as the business entities: auditing, taxation, consulting) as well as professional accountants working under the Employment Contract in one of the economic sectors (trading, production, servicing sphere, public sectors or professional organizations) and work under the contract conditions with a certain business entity.

\section{Essence of the key principles of ethic standards of accountant and auditor.}

According to the Ethic Standards, the professional accountant has to follow the following key fundamental principles: honesty, objectiveness, professional competence and appropriate thoroughness, confidentiality, professional behavior. The important initial condition of the implementation of Ethic Standards for the professional accountants and auditors is the domination of norms of the national legal society, in which different cultural traditions of people and state are focused. In particular, the Standards state that in case the national norm contradicts to the Ethic Standards, the national requirement is of priority. According to the Standards above, the objective of the professional accountant and auditors are interrelated and are constituted in the fulfillment of their duties according to the highest standards for the achievement of the best results and satisfaction of the public interests. The given objectives are called to satisfy the following basic needs, mainly:

- credibility to the information provided and to the corresponding information systems;

- professionalism, which is the grounds for rendering the services, so that the customers do not have any doubts as to the professionalism in the sphere of accounting; 
- the quality of services and confidence that all the services rendered by the professional accountant comply with the highest quality standards;

- confidentiality, i.e. so that the users of the services of professional accountants and auditors are sure about the grounds of professional ethics regulating rendering these services.

According to the given requirements, the above fundamental principles of professional ethics of accountants and auditors were formed. It is important that all these principles are interpreted and perceived equally by all the specialists [4]. Let us consider more in detail the perception of these principles under the conditions of information economy characterized by a wide access of the report users, which ultimately has an immediate impact on administrative decisions taken with regard to the sale and purchase of securities and perspectives of investments without territorial restrictions.

The honesty principles mean the fair attitude towards the business, sincerity and frankness of the professional accountant in the business relations. Honesty, from the point of view of the accountant's professional activity, provides for the avoidance of its relation to the reports, declarations, or other documents, in which the information, to his point of view contains the false or corrupted data, allows for the ungrounded and unjustified conclusions and statements, which, as a result, misinforms the user when it is necessary to make any decision. The second principle is objectiveness, that means the unbiased and fair attitude to the information. For instance, the auditor shall not doubt the decision of the business entity directorate, shall not admit personal assessments based on the affections or antipathy as to the professional qualities of the administrative personnel. For the professional accountants it is necessary to avoid the partiality in the relations with the colleagues, to avoid the conflict of interests. Doubts with regard to the objectiveness arise, as a rule, if there are any essential amounts of the outstanding debts for the work performed by the accountant, in the auditing activity the pressure can be occur from the owners of directors of the enterprise. The Ethic Standards provide for the preventive measures to eliminate the danger of loss of the objectiveness, mainly: the exit of the group from the task; the introduction of the supervision procedure on the part of the directorate (customer); the termination of the financial (business) relations; discussing the issues with the best administrative personnel of the company; discussing the issues with the superior administrative personnel within the company. The third principle is the professional competence and appropriate accuracy, which means that the accountant has to render the professional service in a competent manner, with an appropriate thoroughness, accuracy, he shall constantly maintain and upgrade his high level of knowledge and skills, in order to provide for the highly efficient services to the customer. There are two level-stages of the professional competence: the receipt of the certificate and constant knowledge upgrade, for instance, through the annual advanced training. The fourth principle is the confidentiality, which provides for the preservation of information by the professional accountant, obtained in the process of the services rendering, and prevention of its use or disclosure without the corresponding permission. An exclusion is the situation, in case of availability of the legal or professional right or duty of such information disclosure. This way the auditor may render the information to the other parties with the customer's written permit; at court or in the process of investigation on the initiated disputes; notify the law-enforcement bodies and state agencies about the detected cases of especially severe breaches provided for by the code and in cases the customer involves the auditor to the fraud under false pretences. The fifth principle is the professional behavior, which imposes the obligations upon the auditor to follow the acting law and avoid any actions influencing the aggravation of the professional reputation. The important principle for the auditor is also the autonomy (absence of the direct kin relations and property interests with regard to the inspection subject).

The control for compliance with the requirements of the professional Ethic Standards and basic principles in Ukraine is ensured by the Chamber of Auditors of Ukraine. In case of non-compliance with the professional Ethic Standards the Chamber of Auditors has the right to deprive the auditor or audit firm of the right to practise the auditing activity for certain period of time. In its turn, the auditor preserves its right to appeal the disputable decision at court.

\section{The Ethic Standards for the officials of executive state power authorities.}

The rules of ethical conduct, both for all the specialists in the public sector and in accounting and analytical sciences in particular, are written as a separate Section of the Law of Ukraine «On corruption prevention» [7]. The Article 37 provides the key requirements to the behavior of persons holding the public office. According to these requirements, the public officials during the fulfillment of their duties should comply with the codes (standards) of professional ethics. The general rules of ethic behavior of the public officials and local government representatives should be approved by the central executive power authorities. The law also provides that the local governments, if necessary, shall elaborate and provide for the fulfillment of the industry codes of ethic behavior of their workers in the sphere of administration.

As to the ethical conduct principles, the above-mentioned law states that two factors may be singled out, mainly: first, article 38 states that during the fulfillment of their duties the public officials should strictly observe the requirements of the law and generally accepted ethic conduct standards, be polite in the relations with the publicity, directors, colleagues and subordinates; secondly, according to article 39 the priority of interests for the 
public officials is determined, which is constituted by the activity in favor of the party it represents (state or the territorial community).

As it has already been mentioned, the central executive power authorities approve the general ethical conduct standards for the public officials and local government representatives, which they shall follow while performing their official duties [8]. Thus, in the process of employment to the public office or to the local government, the person should get acquainted with these rules, while the mark about this acquaintance sould be added and preserved in the personal file of the public official. The conduct ethic of the public officials and local government representatives is based on the principles of public service and service at the local governmental agencies determined by the laws of Ukraine "On public service», "On service at the local governmental agencies», «On prevention of corruption». In this case following these rules the public officials should be considered while conducting the annual assessment of their public activity. The heads of the public agencies or local governments, in case they detect the violation of such rules within their competence, should take steps as to the termination of the violation, elimination of its consequences and brining the guilty ones to the disciplinary liability, and in cases of any indications of criminal or administrative delinquencies also notify the National AntiCorruption Bureau agencies.

The consideration of the rules of ethical conduct of the public officials in Ukraine in the context of the Ethic Standards of accountant and auditor showed that the acting regulatory acts on this issue are focused on the principle of priority of the state and public interest, and, thus, occurrence of conflict of interests is also regulated by the acting law. In particular, article 29 of the Law «On corruption prevention» covers the steps of the conflict of interests settlement. If the conflict cannot be settled amicably, then the external regulation of the conflict of interests is provided using one of the five methods: the person removal from the task performance; the application of the external control for the performance of the responsible task by the person; the limitation of the person's access to certain information; the review of the amount of person's administrative duties; the transfer of person to the other office; person dismiss.

\section{Principles of activity of forensic experts.}

The separate group in the accounting and analytical sciences is constituted by the forensic experts. Thus, according to article 10 of the Law of Ukraine «On the forensic enquiry» dated 24.02.1994 the forensic experts may be the persons who have the appropriate knowledge for providing the conclusion on the issues studied, in this case, in the accounting, analysis and control [6]. The same law (article 3) provides the principles of the Forensic Expert Activity, mainly: lawfulness, independence, objectiveness, completeness. Basically, these principles provide for the quality of the conclusions given by the experts. However, from the point of view of the subjects of the forensic expert activity having the right to conduct the inspection, the inadequacy can be noticed of following these principles of separate groups of experts. According to the law, the right to conduct the inspection is given to the public specialized institutions, and to the forensic experts rendering the services based on the licenses. As far as the inspection by such public specialized institutions is concerned, as the scientific research institute of judicial investigation of the Ministry of Justice of Ukraine, the independence principles will be followed more as compared to the expert services of the Ministry of Internal Affairs, the Ministry of Defense, the National Security Agency and State Border Guard Service of Ukraine, as these agencies are characterized by the departmental affiliation of experts who within these ministries work for the same result. This situation occurred involuntarily, in connection with the limited capacities of the research institutions, incapable to conduct the timely expert investigations according to the procedurally determined litigation proceedings. At the same time, in connection with passing the judicial reform in Ukraine, the forensic enquiry is one of the components of the judicial system of highly developed EU countries, while the practice of conducting the enquiries in our country moved beyond the acting law, and is mostly regulated by the statutory instruments, court decisions and explanations of the executive power authorities. Therefore, within the judicial reform in Ukraine, on 30.03.2017 Verkhovna Rada of Ukraine registered the draft law «On forensic expert activity in Ukraine» [2]. According to the suggested draft law (art.5), the forensic expert activity has to be based on six principles, mainly:

1) respect for rights, freedoms and lawful interests of humans and citizens, right and lawful interests of the legal entity;

2) lawfulness;

3) independence of the forensic expert;

4) completeness, objectiveness of the forensic studies;

5) maximum preservation of the investigation objects;

6) compliance with the professional ethic of the forensic expert

Comparing the principles of the forensic and expert activity with the acting law, their growth and reformatting should be outlined. The positive factor is the inclusion of the principles of point 5 and especially point 6 to the list of the principles, related to following the professional ethic of the forensic expert, in our case, as a specialist in the accounting and analytical sciences. At the same time, the reformatting (unification) in c. 4 does not have any scholarly background, which is explained by the possibility of occurrence of the situation, when all the materials given to the expert are studied to the fullest extent, but the objectiveness is violated and 
vice versa, if the principle of objectiveness is followed by the expert but the case materials are not studied to the fullest extent. Accepting the importance of the suggested changes, it should be noted that the fact was disregarded that during the last decade the professional activity of experts is developed, who do not belong to the state expert institutions. The private companies were incorporated, which unified the experts and specialists in the accounting, analysis and control. In connection with the expansion of the expert activity beyond the state institutions, the necessity arises of the strict liability for the violation of principles amongst these experts, with the simultaneous support of the competition between all suppliers of the expert services and prevention of monopolies. To our point of view, the personal criminal liability of the expert for rendering the false conclusions, as well as the disciplinary and administrative measures for the inappropriate fulfillment of forensic expert liabilities equally guarantee the appropriate conducting of inspections by experts both of the state institutions and the ones who do not work at the state expert institutions.

Conclusions and prospects for further researches. Thus, under the conditions of information economy, the risks of the administrative solutions mostly depend upon the reliability of the data given by the specialists in the accounting and analytical sciences during the fulfillment of their professional duties and their compliance with the fundamental ethic principles, established by the Ethic Standards of professional accountants, laws of Ukraine regulating the functions of the public officials and forensic experts. Their fulfillment is dramatically important, as this directly influences not only the prestige of the profession, but also on the public credibility to such specialists in all sectors of economy.

National forensic enquiry cannot exist isolated, i.e. only within the separate state. It will not perform efficiently its functions of insuring the law-enforcement activity beyond the integration with the international community. Therefore, there is a necessity of expert possibilities and resources integration, as well as the work experience exchange, the accounting of modern of science and engineering, exclusion of duplication of the scholarly and methodological insurance, regional distribution of tasks between the forensic and expert institution, creation of the specialized expert directions.

Forensic and expert activity of the state has to comply with the national principles and international legal and professional standards. The conclusion drawn by the experts of one and the same state shall have the evidence valid for the courts of other states. The experts of different states cannot be isolated from each other and from the law-enforcement systems of these states; they should become the full-fledged subjects of the international law-enforcement relations, realize together the potential of the national forensic enquiry, science and engineering. The suggested changes to the principles of the forensic and expert activity need more scholarly grounded format and shall be close to the internationally acknowledged Ethic Standards and shall facilitate the creation of the competitive environment among all specialists of the accounting and analytical sciences in the context of their personal liability.

Surely, the activity of accountants, auditors and exports is not deprived of various dangers, however, they can be avoided or at least their impact can be reduced to the acceptable level, taking all the preventive measures with the use of information resources of the Internet.

\section{References:}

1. Бондар В.П. Принципи професійної етики аудитора України та проблеми їх реалізації / В.П. Бондар // Вісник ЖДТУ. - 2008. - № 2 (44). - С. 13-21.

2. Проект Закону Про судово-експертну діяльність в Україні : станом на 30 березня 2017 р. : № 6264 [Електронний ресурс] - Режим доступу : http://search.ligazakon.ua/1_doc2.nsf/link1/JH4U000A.html.

3. Господарсько-процесуальний кодекс України [Електронний ресурс] - Режим доступу http://zakon3.rada.gov.ua/laws/show/1798-12.

4. Кодекс етики професійних бухгалтерів / Редакція 2012 р. - К., 2014. - 172 с.

5. Голов С.Ф. Бухгалтерський облік за міжнародними стандартами: приклади та коментарі / С.Ф. Голов, B.М. Костюченко. - К. : Лібра, 2001. - 840 с.

6. Закон України : станомна 24 лютого 1994 року : № 4038-XII «Про судову експертизу» [Електронний pecypc] - Режим доступу : http://zakon2.rada.gov.ua/laws/show/4038-12.

7. Закон України «Про запобігання корупції» : станом на 03 серпня 2017 : підстава 2136-19 [Електронний pecypc] - Режим доступу : http://zakon0.rada.gov.ua/laws/show/1700-18.

8. Закон України «Про затвердження Загальних правил етичної поведінки державних службовців та посадових осіб місцевого самоврядування» [Електронний ресурс]. - Режим доступу : http://zakon2.rada.gov.ua/laws/show/z1203-16.

9. Редько О.Ю. Кодекс професійної етики аудитора. Професійна незалежність аудитора (Науково-практичний коментар) / О.Ю. Редько, О.Б. Рижакова, К.О. Редько. - 2010. - К.

10. Швець B.C. Науково-практичний внесок Юліана Павликовського у розвиток економічних наук / B. С. Швець // Торгівля, комерція і підприємництво : збірник наук. праць ; під ред. В.В. Апопій, П.О. Куцик, В.О. Шевчук та інші. - Львів : Львівська комерційна академія, 2014. - Вип. 16. - С. 171-175.

\section{References:}

1. Bondar, V.P. (2008), «Pryncypy profesijnoi' etyky audytora Ukrai'ny ta problemy i'h realizacii'», Visnyk ZhDTU, No. 2 (44), Pp. 13-21. 
2. Proekt Zakonu (2017), Pro sudovo-ekspertnu dijal'nist' v Ukrai'ni : stanom na 30 bereznja, No. 6264 http://search.ligazakon.ua/__doc2.nsf/link1/JH4U000A.html

3. Verhovna Rada Ukrai'ny «Gospodars'ko-procesual'nyj kodeks Ukrai'ny», available at: http://zakon3.rada.gov.ua/laws/show/1798-12

4. Kodeks etyky profesijnyh buhgalteriv (2014), Redakcija 2012 r, K., 172 p.

5. Golov, S.F. and Kostjuchenko, V.M. (2001), Buhgalters'kyj oblik za mizhnarodnymy standartamy: pryklady ta komentari, Libra, K., 840 p.

6. Verhovna rada Ukrai'ny (1994), Zakon Ukrai'ny «Pro sudovu ekspertyzu», stanom na 24 ljutogo, No. 4038-XII, available at: http://zakon2.rada.gov.ua/laws/show/4038-12

7. Verhovna rada Ukrai'ny (2017), Zakon Ukrai'ny «Pro zapobigannja korupcii'», stanom na 03 serpnja, pidstava 2136-19, available at: http://zakon0.rada.gov.ua/laws/show/1700-18

8. Verhovna rada Ukrai'ny, Zakon Ukrai'ny «Pro zatverdzhennja Zagal'nyh pravyl etychnoi' povedinky derzhavnyh sluzhbovciv ta posadovyh osib miscevogo samovrjaduvannja», available at: http://zakon2.rada.gov.ua/laws/show/z1203-16

9. Red'ko, O.Ju., Ryzhakova, O.B. and Red'ko, K.O. (2010), Kodeks profesijnoi' etyky audytora. Profesijna nezalezhnist' audytora (Naukovo-praktychnyj komentar), Kyi'v.

10. Shvec', V.Je. (2014), «Naukovo-praktychnyj vnesok Juliana Pavlykovs'kogo u rozvytok ekonomichnyh nauk», Torgivlja, komercija i pidpryjemnyctvo, zbirnyk nauk. prac', in Apopij, V.V., Kucyk, P.O., Shevchuk, V.O. and others (ed.),L'vivs'ka komercijna akademija, L'viv, Vol. 16, Pp. 171-175.

Shvets Volodymyr Yevhenovych - PhD in economics, associate professor, professor of the Department of accounting and audit of the Ivan Franko National University.

Scientific interests:

- methodological and historical issues of accounting, analysis and control of the commercial activity in Ukraine;

- economic analysis and control of the antiques market in Ukraine;

- regularities of formation and development of the accounting and analytic systems of commercial subjects.

Pavlik Iryna Yevhenivna - PhD Fellow of the Department of accounting and audit of the Ivan Franko National University.

Scientific interests:

- $\quad$ organization of the accounting and analytic systems of commercial subjects in the agrarian sector of economics).

Tel.: +38 (067) 81-09-865.

E-mail: ira_pavlik@ukr.net.

The article was sent to the editorial board on 22.05.2018. 